\title{
Treatment of malignancy-associated hypercalcemia with cinacalcet: a paradigm shift
}

\author{
Sondra O'Callaghan and Hanford Yau \\ Endocrinology, Diabetes \& Metabolism, Orlando VA Healthcare System, Orlando, Florida, USA \\ Correspondence should be addressed to S O'Callaghan or H Yau: acorporeal@comcast.net or hanfordyau@gmail.com
}

\begin{abstract}
Palliation of symptoms related to malignancy-associated hypercalcemia (MAH) is essential and clinically meaningful for patients, given the continued poor prognosis, with high morbidity and mortality associated with this disease process. Historically, agents have been temporizing, having no impact on patient morbidity nor survival. We suggest that cinacalcet can be an efficacious agent to be taken orally, reducing patients' time in the hospital/clinic settings. It is well-tolerated and maintains serum calcium levels in the normal range, while targeted cancer treatments can be employed. This has a direct, major impact on morbidity. Maintaining eucalcemia can increase quality of life, while allowing targeted therapies time to improve survival. Given that our case (and others) showed calcium reduction in $\mathrm{MAH}$, there is promising evidence that cinacalcet can be more widely employed in this setting. Future consideration should be given to studies addressing the efficacy of cinacalcet in calcium normalization, improvement of quality of life, and impact on survival in patients with MAH. Though the exact mechanism of action for cinacalcet's reduction in calcium in this setting is not currently known, we can still afford patients the possible benefit from it.
\end{abstract}

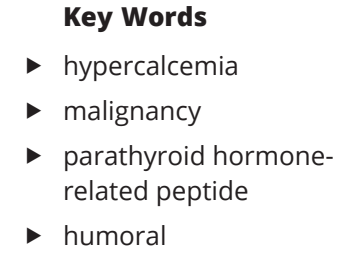

Endocrine Connections (2021) 10, R13-R24

\section{Introduction}

Malignancy-associated hypercalcemia (MAH) has long been described in medical literature and has posed a therapeutic conundrum. Over decades, this form of hypercalcemia has eluded conventional therapies, in that, it responds only temporarily and often is refractory. Clinically, for the patient it negatively impacts quality of life, and patients can succumb to hypercalcemic crisis. Indeed, MAH not uncommonly, constitutes a metabolic oncologic emergency $(1,2)$.

Malignancy-associated hypercalcemia is the second most common cause of hypercalcemia in the general population and the most common cause of hypercalcemia among patients in the inpatient setting. Incidence has been reported at 15 cases per 100,000 annually, and approximately $20-30 \%$ of patients with cancer develop MAH (3). The clinical symptomatology of hypercalcemia depends on the degree of elevation of calcium. The patient may be asymptomatic, has few constitutional symptoms, or may develop neurovascular symptoms resulting in a state of metabolic emergency (1).

\section{Survival}

Historically, once MAH presents, up to $50 \%$ of patients die in an average of 30 days, and up to $75 \%$ die within 3 months $(4,5)$. It has been suggested that therapy for hypercalcemia is interim, with no effect on survival; this has been observed over time $(4,6)$. Despite advances in therapeutics, survival after diagnosis of MAH has not changed over the decades. In the 1980s, patients with bone metastases from breast cancer were observed to survive about 3 months after the onset of hypercalcemia (7). Median survival in patients with squamous cell carcinoma
This work is licensed under a Creative Commons Attribution-NonCommercial-NoDerivatives 4.0 enternationad ticense.ifica.com at 04/26/2023 12:14:45PM 
and hypercalcemia was 17-64 days $(8,9)$. In a series of patients with parathyroid hormone-related peptide (PTH-RP) mediated hypercalcemia associated with solid organ malignancy, the median survival was 52 days (10). A 2017 study revealed similar survival rates with the cohort having median survival of 40 days (11). Neither degree of elevation of hypercalcemia nor degree of elevation of PTH-RP has shown an associated change in survival (10). This recapitulates early studies showing that the absolute level of calcium is not a good prognosticator, but the mere presence of hypercalcemia portends poor prognosis (6).

Survival may be impacted by controlling the calcium level, to the extent that patients whose calcium is normal or near-normal are not succumbing to hypercalcemiarelated complications (e.g. cardiac arrhythmias) as a cause of death. It is thought that controlling calcium can increase quality of life, reduce morbidity, and give time for targeted cancer therapy to be implemented (12). Ramos et al. showed that after MAH was diagnosed, there was a lengthened survival in those patients whose calcium normalized and were subsequently able to receive chemotherapy (11). Nonetheless, their study confirmed that for patients developing MAH, there remains dismal prognosis. Specifically looking at effects on morbidity and mortality, bisphosphonate therapy has brought about no change in these parameters (13). Ling et al. confirm this, observing that patients died within 2 months, while some who received bisphosphonate died within 3 months of developing hypercalcemia (14). They noted that tumor type, time from tumor diagnosis to hypercalcemia, nor level of serum calcium impacted survival. It has also been observed that there is no difference in survival in patients treated with different anti-hypercalcemic agents (5).

Historic and current observations continue to confirm that MAH portends a poor prognosis (8). In fact, a bedside prognostic score has been developed and used in studies evaluating hypercalcemia as an independent prognostic factor $(9,15)$. Certainly, newer targeted anti-cancer therapies may extend overall survival in cancer patients and can lengthen progression time to malignancyassociated complications such as bone metastases and/or hypercalcemia. There are currently no studies describing the impact of newer, targeted anti-cancer therapies and their impact on MAH and survival. Is it possible that if hypercalcemia is normalized, patients can experience fewer morbidities (those that relate to hypercalcemia) and have extended survival simply because they can continue with targeted anti-cancer therapies?

\section{Historical perspective of classification and pathophysiology}

In 1941, Albright proposed that tumors be tested for parathyroid hormone (PTH), as it seemed a hormone causing PTH-like effects were produced from tumors (16). Since this hormone early on was thought to be PTH, the process was termed ectopic PTH syndrome. Still in the 1970s, more studies showed that tumors can secrete a hormone other than PTH which exerts PTH-like effects $(17,18)$. Though this PTH-like substance remained elusive for decades, it had been concluded that the prior known 'ectopic PTH syndrome' was very rare $(<1 \%$ of cases), as most cases of MAH had no detectable PTH $(3,19,20)$. As these cases continued to be described, the term 'pseudohyperparathyroidism' was given in lieu of ectopic PTH syndrome. To describe the process more accurately, more than 30 years after Albright's supposition, the term 'humoral hypercalcemia of malignancy' (HHM) was proposed (21).

Researchers postulated that there were many factors that drive $\mathrm{MAH}$, including bone resorption by local tumor growth, substances causing bone resorption, and renal effects of PTH-like factors $(22,23,24)$. Previously, it was estimated that PTH-like factors were produced by at least $75-80 \%$ of solid tumors associated with hypercalcemia (23); the current estimate remains at $-80 \%$ (3).

\section{Current perspective of classification and pathophysiology}

Various pathophysiologic mechanisms have been found to be responsible for MAH. Overall, general mechanisms are osteolytic and humoral (Table 1). Mechanisms within these two main states are further considered briefly.

\section{Humoral hypercalcemia of malignancy (HHM)}

Most cases of MAH are driven by means which are humoral (3). The mechanism is most frequently via tumor

Table 1 General mechanisms of malignancy-associated hypercalcemia.

\begin{tabular}{lll}
\hline Osteolytic & & Humoral \\
\cline { 1 - 2 }$\uparrow$ Bone resorption & $\uparrow \mathrm{PTH}-\mathrm{RP}$ \\
Local destruction by metastasis & $\uparrow \mathrm{PTH}$ \\
Humoral factors & $\uparrow 1,25(\mathrm{OH})_{2} \mathrm{D} 3$ \\
\hline
\end{tabular}

1,25(OH) 2 D3, 1,25-dihydroxy vitamin D3; PTH, parathyroid hormone; PTH-RP, parathyroid hormone-related peptide.

This work is licensed under a Creative Commons Attribution-NonCommercial-NoDerivatives 4.0 Internationab ficense.ifica . com at $04 / 26 / 2023$ 12:14:45PM 
secretion of PTH-RP, and/or other humoral factors. Most often, it is observed in cancers involving solid tumors (without bone metastases), but it can manifest in a variety of cancers.

Another mechanism that can drive HHM is the elevation of 1,25-dihydroxy vitamin $\mathrm{D}\left(1,25(\mathrm{OH})_{2} \mathrm{D} 3\right)$, leading to increased absorption of calcium. This is mainly seen in hematologic cancers like lymphomas, and it has been reported in ovarian dysgerminomas $(3,25,26,27)$.

True ectopic PTH secretion by tumors is the least common mechanism to drive HHM; there have been cases reported in neuroendocrine tumors $(3,20)$.

Specifically speaking to cases of HHM driven by PTH-RP, it was first commonly observed in cancers involving solid tumors but without bone metastases. Bone metastases had long been described in breast cancer, yet without production of PTH-RP. However, HHM has been described coincident with bone metastases, and a PTH-like peptide was identified in breast cancer cells in $(28,29,30)$. Furthermore, the first report of expression of the PTH-RP gene and the production of PTH-RP has been documented in multiple myeloma with marked elevation of serum calcium, evidence that a humoral component can also contribute to the skeletal complications and hypercalcemia in myeloma (31). Of note, patients with normocalcemic states have been found to have tumors expressing PTH-RP, suggesting that levels in circulation may not have been high enough to achieve and maintain a hypercalcemic state (32). There can be overlap in the way tumor activity results in a hypercalcemic state (Fig. 1).

\section{Osteolytic}

Other factors that can drive MAH are osteolytic. Osteoclast-mediated destruction and osteosclerosis

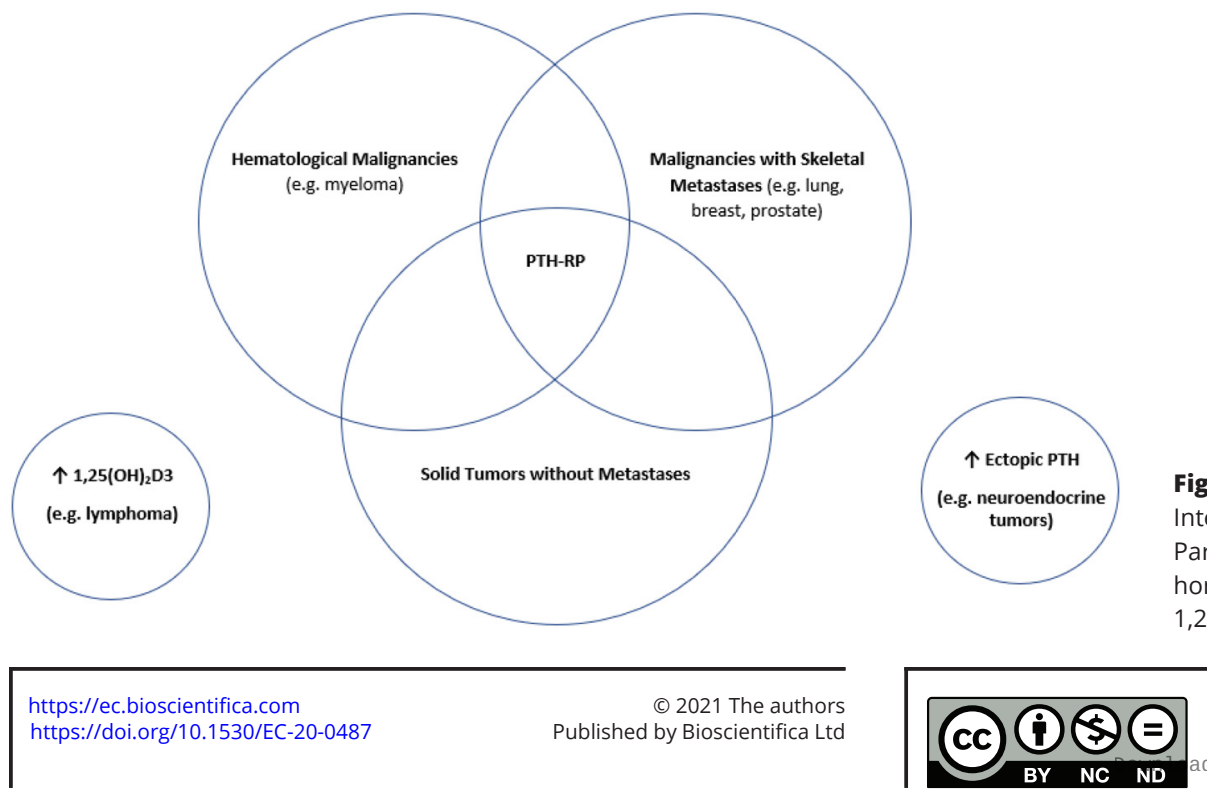

Figure 1

Intersecting and independent etiologies of HHM. Parathyroid hormone (PTH); parathyroid hormone-related peptide (PTH-RP). 1,25-dihydroxy vitamin $\mathrm{D}\left(1,25(\mathrm{OH})_{2} \mathrm{D} 3\right)$. due to impaired/increased osteoblastic activity are the predominant forces contributing to the formation of bone lesions. Hypercalcemia can develop when the predominant force is osteoclastic, and hypocalcemia can develop due to calcium sequestration when the driving force is osteoblastic. Although cancers can exhibit predominantly increased resorption or formation of bone, a mixed picture is not uncommonly observed $(33,34,35)$. Increased resorption and impaired formation are driven by local factors and humoral tumor factors produced by the tumor. Bone metastases themselves ultimately can destroy bone locally and exert mass effect. Thus, another mechanism for MAH is explained by local osteolytic effects resulting in hypercalcemia, seen mainly in cancers with significant skeletal lysis and/or increased resorption like breast cancer and multiple myeloma, respectively.

\section{PTH-RP in perspective}

Parathyroid hormone-related peptide is in many tissues and is involved in normal physiology $(36,37)$. In normal states, PTH-RP is not elevated. In a pathologic state like HHM, PTH-RP is produced and secreted in excess, therefore, it was proposed that PTH-RP could serve as a tumor marker (38).

Before its actual identification, this PTH-like protein from tumor extracts was described as having multiple times the biologic activity of PTH, being a different form of PTH, and working in concert with other substances resulting in hypercalcemia $(17,39)$. In the 1980s, parathyroid hormone-like proteins identified in breast (30) and lung cancers displayed homology to PTH, yet with greater biologic activity $(40,41)$. This increased effect on bone and renal activity can explain the development 
of hypercalcemia above the threshold of the body's capability to maintain normal calcium homeostasis and can account for the relative severity and acuity of MAH compared with PTH-mediated hypercalcemia. Researchers reported a PTH-like protein that can stimulate adenylate cyclase in the renal cortices $(30,42)$ and promote calcium retention consistent with the clinical manifestations of HHM, pointing to the kidney as a major therapeutic target for this disease state (42).

Historically, the PTH-RP assays were developed and used in labs for research purposes. Currently, commercial labs have developed and offer PTH-RP testing, though there is currently great need for standardization and improvement in specificity, sensitivity, and analytic precision due to the various isoforms of the molecule (43).

\section{Homology of PTH to PTH-RP as well as their genetic homology}

Parathyroid hormone-related protein purified from lung and breast cancer cell lines was cloned; an amino acid sequence with homology to human PTH was observed (30, 40, 41), explaining its PTH-like effects. Considering the homology of PTH and PTH-RP, it was inferred that there was homology in the genes encoding them (40). In 1989, the human PTH-RP gene was characterized (44), structurally confirming the relatedness of the PTH-RP and PTH genes (chromosome 12 and 11, respectively) and showing that three distinct PTH-like proteins are products of the PTH-RP gene. Knowing the structural and genetic similarities of PTH and PTH-RP, it comes as no surprise that there are similarities and overlap in their functional activities relating to calcium homeostasis.

\section{The type 1 parathyroid hormone receptor (PTH1R)}

Based on review of prior and ongoing studies, it was surmised in 1989 that the hormone driving MAH acted on PTH target cells at the PTH receptor (19). It is now known that PTH and PTH-RP share the PTH1R to evoke their physiologic actions. After a very elegant literature review discussing the interaction and contribution of PTH1R and the calcium-sensing receptor (CaSR) signaling pathway to the development and perpetuation of breast cancer bone metastases, Yang suggested that future therapeutic modalities target those agents that can influence PTH-RP, the PTH1R, and CaSR signaling pathways (45).

\section{The calcium-sensing receptor}

The CaSR on the surface of the parathyroid gland chief cell is the principal regulator of PTH synthesis, secretion, and gene expression by mediating the inhibitory action of calcium (36). In the calcitonin-secreting C-cells of the thyroid, it mediates the stimulatory action of high calcium on calcitonin secretion. Cinacalcet is a calcimimetic that directly lowers PTH levels by increasing the sensitivity of the CaSR to extracellular calcium. In 1998, the first therapeutic use of this novel agent was described in a patient with parathyroid carcinoma and hypercalcemia (46) resulting in a reduction in calcium and PTH levels. Despite disease progression resulting in PTH increases, calcium remained stable with various dosage adjustments. It has been suggested that cinacalcet may potentially be useful in cancers with ectopic production of PTH (20, 47). Review of studies up to 2001, suggested a physiologic relationship between the CaSR and the secretion of PTH-RP (37); a relationship on which to focus future therapy.

\section{Pharmacotherapy for MAH}

Reducing tumor burden, can reduce or control calcium at least temporarily (17). This can be by surgical or chemotherapeutic means. Targeted cancer treatment, when successful, can slow progression to a state of hypercalcemia.

Certainly, reducing exogenous influences on calcium burden are paramount. This can be achieved by removing calcium supplements orally, parenterally, and in dialysate. Low calcium or calcium-free dialysate is effective in hypercalcemic crisis when initial treatments fail, or in the setting of fluid overload or renal failure (48). Discontinuation of agents that raise serum calcium (e.g. thiazides or lithium) reduces calcium burden otherwise imposed by the hypercalcemic state. Avoiding immobility and volume depletion and employing volume expansion with isotonic saline where necessary is helpful. Hydration and diuresis with a loop diuretic, directly increasing calcium excretion, have been used to lower serum calcium. However, this is not a safe option in all patients, and it can lead to dehydration with rebound hypercalcemia.

It was thought that long- term management of $\mathrm{MAH}$ needed to focus on development of agents targeting bone resorption (39). Some early agents employed to lower calcium were found to be unsafe, are no longer in use, and will not be discussed. For 30 years, bisphosphonates were the focus of studies and were the mainstay of therapy

This work is licensed under a Creative Commons Attribution-NonCommercial-NoDerivatives 4.0 elnternationad dicense ifica. com at 04/26/2023 12:14:45PM 
for MAH. In 1977 etidronate was the first diphosphate used to treat hypercalcemia. It slowed bone resorption, thereby affecting calcium metabolism to reduce serum levels. Working similarly was pamidronate, which was approved 14 years later (1991); pamidronate became the first bisphosphonate specifically indicated for treatment of MAH. The next bisphosphonate approved for MAH was zolendronate (2001). These agents are dosed intravenously (IV) in clinic or hospital settings. It can take a few days to see a reduction in calcium levels, and this reduction is temporary.

Denosumab came to market in 2010 as the first novel agent in 30 years targeted at inhibiting bone resorption. It is a human MAB that binds to and inhibits the receptor activator of nuclear factor kappa-B ligand (RANKL), the primary mediator of bone resorption, via activation of osteoclasts. Employing denosumab, Hu et al. observed a $70 \%$ response rate $($ response $=$ calcium level $<2.8 \mathrm{mmol} / \mathrm{L}$ ) for patients with $\mathrm{MAH}$, and the median duration of response was 9 days (49). The longest duration was 104 days. It is promising that this agent can, in some cases, bring about a longer period of lowered calcium levels.

Glucocorticoids can be effective in cases of HHM where overproduction of $1,25(\mathrm{OH})_{2} \mathrm{D} 3$ predominantly drives hypercalcemia. Calcitonin lowers blood calcium by promoting calcium incorporation into bone, however, the effects are minimal and transient.

Historically, the only treatment for hypercalcemia in patients with renal failure was dialysis (50). Currently, denosumab can be used without need for dosage adjustment in renal failure. Cinacalcet, though not indicated for treatment of MAH, can safely reduce calcium levels in renal failure or renal-compromised patients. Therefore, safety in this population is established.

Cinacalcet was approved for use in 2004 and is indicated for patients with secondary hyperparathyroidism with chronic kidney disease on dialysis, hypercalcemia in patients with parathyroid carcinoma, and severe hypercalcemia in patients with primary hyperparathyroidism who are unable to undergo parathyroidectomy. Considering the shared homology of PTH and PTH-RP and given cinacalcet's current role in controlling PTH-mediated hypercalcemia, Can there be a key role for cinacalcet in treating other hypercalcemic states, especially those driven by PTH-RP? It had been suggested that MAH refractory to bisphosphonate therapy can be treated with denosumab (51). It is now proposed that cinacalcet can be used as adjunctive therapy in HHM (and possibly other forms of MAH) successfully and safely over the long-term.

\section{Cases of cinacalcet-treated MAH}

\section{The Netherlands}

One of the first cases using cinacalcet in MAH was described in 2012 by Bech (52) and colleagues. In this case, efficacy of cinacalcet as a suppressor of PTH-RP production was explored. A 57 -year-old male with stage cT4N3M1b squamous cell lung carcinoma developed severe, recurrent MAH. On presentation, the patient had symptomatic hypercalcemia with the following laboratory values: PTH $<1.0 \mathrm{pmol} / \mathrm{L}(1.3-6.8 \mathrm{pmol} / \mathrm{L})$, PTH-RP 5.8 $\mathrm{pmol} / \mathrm{L}$ or $55 \mathrm{ng} / \mathrm{L}(<0.6 \mathrm{pmol} / \mathrm{L}$ or $6 \mathrm{ng} / \mathrm{L})$, and calcium $4.5 \mathrm{mmol} / \mathrm{L}$ (routine clinical chemistry assays Roche Diagnostics). The patient was administered normal saline, calcitonin, and pamidronate over 2 weeks. These measures achieved a calcium of $2.8 \mathrm{mmol} / \mathrm{L}$ which increased to 4.4 $\mathrm{mmol} / \mathrm{L}$ after 2 weeks. For the next 5 days, normal saline was resumed along with calcitonin and a single dose of zolendronate. Nonetheless, the calcium and PTH-RP were $3.5 \mathrm{mmol} / \mathrm{L}$ and $13.3 \mathrm{pmol} / \mathrm{L}$ (125 ng/L), respectively.

At this point, with the patient's consent, cinacalcet was started and continued for 15 days while chemotherapy with carboplatin and gemcitabine was initiated. During this first cycle, the calcium dropped to a hypocalcemic level, and PTH-RP came down. Cinacalcet was discontinued, bringing about a rise in PTH from undetectable to 5.1 $\mathrm{pmol} / \mathrm{L}$ with a normalization of serum calcium. There were three more cycles of combination chemotherapy without cinacalcet. After the fourth cycle, the calcium rose to $3.5 \mathrm{mmol} / \mathrm{L}$. The patient was hospitalized, and cinacalcet was started along with hydration and a dose of zolendronate. Calcium improved to $3.0 \mathrm{mmol} / \mathrm{L}$, and the patient was discharged on the cinacalcet. Hospitalization was required after 9 days, and a dose of zolendronate was given. Due to disease progression, the patient succumbed to his illness after 2 weeks. It was concluded that about $71 \%$ of the variance in serum calcium correlated with PTH-RP levels and that PTH-RP reduction may be a result of cinacalcet use.

\section{United States of America}

Sternlicht \& Glezerman report a case of metastatic renal cell carcinoma in 2013 (53). Laboratory reference ranges provided are PTH-RP 14-27 pg/mL (14-27 ng/L) and PTH $12-88 \mathrm{pg} / \mathrm{mL}$ (1.3-9.3 pmol/L). After bisphosphonate and denosumab therapy, the calcium was $14.2 \mathrm{mg} / \mathrm{dL}$ (3.6 $\mathrm{mmol} / \mathrm{L})$, PTH $10 \mathrm{pg} / \mathrm{mL}(1.1 \mathrm{pmol} / \mathrm{L})$, and PTH-RP 114 $\mathrm{pg} / \mathrm{mL}(114 \mathrm{ng} / \mathrm{L})$. Cinacalcet was started and titrated, and at 10 weeks calcium improved to $10.1 \mathrm{mg} / \mathrm{dL}(2.5 \mathrm{mmol} / \mathrm{L})$

This work is licensed under a Creative Commons Attribution-NonCommercial-NoDerivatives 4.0 International License.ifica com at $04 / 26 / 2023$ 12:14:45PM 
with PTH-RP $159 \mathrm{pg} / \mathrm{mL}$ (159 ng/L). Their theory is that cinacalcet may have a role in the treatment of MAH.

\section{New Zealand}

A case presented by abstract at the Endocrine Society's 97th Annual Meeting by Whitfield and Carroll (54) describes a 54- year-old female diagnosed with inoperable gastroenteropancreatic neuroendocrine tumor (GEPNET). The tumor was treated with octreotide. Within 1 year, the calcium rose to $3.0 \mathrm{mmol} / \mathrm{L}(2.2-2.6 \mathrm{mmol} / \mathrm{L})$ with PTH $<0.6 \mathrm{pmol} / \mathrm{L}(1.5-6.0 \mathrm{pmol} / \mathrm{L})$ and PTH-RP 3.3 $\mathrm{pmol} / \mathrm{L}$ or $31 \mathrm{ng} / \mathrm{L}(0.0-1.5 \mathrm{pmol} / \mathrm{L}$ or $0-14 \mathrm{ng} / \mathrm{L})$. Tumor embolization failed, and funded sunitinib therapy was unavailable. Three weekly infusions of zolendronate and normal saline failed to control calcium and its symptoms, therefore cinacalcet was initiated and titrated. The calcium improved to $2.9 \mathrm{mmol} / \mathrm{L}$ within 1 month and remained $2.5-2.9 \mathrm{mmol} / \mathrm{L}$ for 18 months (all the while patient remained on octreotide). The observation was that cinacalcet may be a useful therapeutic option for MAH.

\section{Belgium}

Another case of a neuroendocrine (NET) tumor with hypercalcemia has been described by Valdes-Socin and colleagues in 2017 (55). A 52- year-old male presented with an unresectable, well-differentiated, metastatic pancreatic NET. Laboratory reference ranges provided are calcium 2.2-2.6 mmol/L and PTH 12-58 pg/mL (1.3-6.2 $\mathrm{pmol} / \mathrm{L})$

Calcium was $3.5 \mathrm{mmol} / \mathrm{L}$ with $\mathrm{PTH}<4 \mathrm{pg} / \mathrm{mL}(0.4$ pmol/L); PTH-RP could not be measured. Several cycles of streptozotocin-adriamycin and FOLFOX (folinate, fluorouracil, oxaliplatin) were given. While the PTH level remained low at $19 \mathrm{pg} / \mathrm{mL}(2.0 \mathrm{pmol} / \mathrm{L})$, the tumor mass and calcium level $(2.6 \mathrm{mmol} / \mathrm{L})$ improved. After 3 months, the calcium and PTH were $2.9 \mathrm{mmol} / \mathrm{L}$ and $<2$ $\mathrm{pg} / \mathrm{mL}(0.2 \mathrm{pmol} / \mathrm{L})$, respectively. Octreotide was given without clinical impact. Calcium had risen to $3.1 \mathrm{mmol} / \mathrm{L}$ and was refractory to saline fluids, diuretics, recombinant calcitonin, and zolendronate. Compassionate treatment with cinacalcet was initiated. Calcium levels responded down to 2.8 then $2.6 \mathrm{mmol} / \mathrm{L}$ over 3 months. Shortly thereafter, sunitinib was introduced. After 1 month of combined sunitinib-cinacalcet therapy, the calcium fell into the hypocalcemic range at $2.1 \mathrm{mmol} / \mathrm{L}$ with PTH $78 \mathrm{pg} / \mathrm{mL}$ (8.3 pmol/L). Cinacalcet was discontinued; sunitinib treatment was continued for 4 years with normal calcium levels.
The authors conclude that cinacalcet lowered calcium and improved clinical condition and that sunitinib contributed to lowering calcium.

\section{Greece}

Asonitis and colleagues (56) presented a case of a 69-yearold female with a 6-year history of infiltrating ductal and lobular mammary carcinoma with bone metastases. The patient received zolendronate and radioactive samarium due to thoracic, lumbar spine, and pelvic lesions. Of note, the zolendronate was given for bone metastases, not hypercalcemia, and the last dose had been given 2 years prior to presentation with hypercalcemia. Laboratory reference ranges provided are calcium $8.6-10.2 \mathrm{mg} / \mathrm{dL}$ (2.3-2.6 mmol/L) and PTH 8-76 pg/mL (8-76 ng/L).

At presentation, the calcium level was $15.2 \mathrm{mg} / \mathrm{dL}$ (3.8 mmol/L) with PTH $6.5 \mathrm{pg} / \mathrm{mL}(0.6 \mathrm{pmol} / \mathrm{L})$. The PTH-RP could not be measured. Treatment consisted of normal saline, furosemide, and zolendronate. On day 2, the calcium was $12.9 \mathrm{mg} / \mathrm{dL}(3.2 \mathrm{mmol} / \mathrm{L})$, and calcitonin and hydrocortisone were administered. On day 5, the calcium was $10.4 \mathrm{mg} / \mathrm{dL}(2.6 \mathrm{mmol} / \mathrm{L})$, and the patient was discharged on methylprednisolone, furosemide, reduced calcium intake, and increased water intake. Five days later, denosumab was added due to a calcium level of 13.6 $\mathrm{mg} / \mathrm{dL}$ (3.4 mmol/L). After 3 weeks, cinacalcet was added to the regimen, since the calcium plateaued at $13.3 \mathrm{mg} / \mathrm{dL}$ (3.3 mmol/L). By 2 weeks, the calcium level improved to $11.7 \mathrm{mg} / \mathrm{dL}$ (2.9 mmol/L), and the cinacalcet was titrated. At this point the denosumab was administered monthly. The calcium was normal (9.6 mg/dL (2.4 mmol/L)) after 3 weeks and remained normal for 1.5 months. To confirm efficacy, cinacalcet was held, resulting in a rise of calcium by $1.7 \mathrm{mg} / \mathrm{dL}(0.4 \mathrm{mmol} / \mathrm{L})$. In total, the patient benefitted from stable calcium levels for 11 months with cinacalcet. The authors suggest that cinacalcet can be an effective therapeutic option for MAH.

\section{United States of America}

Recently, authors report a case of an 81 -year-old female suffering from non-small cell lung cancer (NSCLC) and recurrent bladder cancer with HHM refractory to traditional therapy (57). Laboratory reference ranges provided are calcium 8.5-10.1 $\mathrm{mg} / \mathrm{dL}(2.1-2.5 \mathrm{mmol} / \mathrm{L})$, PTH 18-85 pg/mL (1.9-9.0 pmol/L), and PTH-RP 0-2 $\mathrm{pmol} / \mathrm{L}(<19 \mathrm{ng} / \mathrm{L})$.

The NSCLC was showing progression, so nivolumab was started. Five weeks later the calcium started to rise

This work is licensed under a Creative Commons Attribution-NonCommercial-NoDerivatives 4.0 International License ifica com at $04 / 26 / 2023 \quad 12: 14: 45 \mathrm{PM}$ 
(10.6 mg/dL (2.7 mmol/L)). Thereafter, due to progressive clinical deterioration, she was hospitalized with calcium $12.7 \mathrm{mg} / \mathrm{dL}$ (3.8 mmol/L), PTH $<6 \mathrm{pg} / \mathrm{mL}(<0.7 \mathrm{pmol} / \mathrm{L})$, and PTH-RP $3.3 \mathrm{pmol} / \mathrm{L}(31 \mathrm{ng} / \mathrm{L})$. Treatment consisted of pamidronate and fluids. After 4 days, the calcium was $8.2 \mathrm{mg} / \mathrm{dL}(2.1 \mathrm{mmol} / \mathrm{L})$. She was readmitted due to symptoms with calcium $11.1 \mathrm{md} / \mathrm{dL}(2.8 \mathrm{mmol} / \mathrm{L}), \mathrm{PTH}$ $5.8 \mathrm{pg} / \mathrm{mL}$ (0.6 pmol/L), and PTH-RP $42 \mathrm{pmol} / \mathrm{L}$ (396 ng/L). Treatment consisted of zolendronate and fluids. Within 2 days the calcium was $8.7 \mathrm{mg} / \mathrm{dL}(2.2 \mathrm{pmol} / \mathrm{L})$ with a rise to $10.1 \mathrm{mg} / \mathrm{dL}(2.5 \mathrm{mmol} / \mathrm{L})$ in 3 days. Denosumab was given, but readmission was required in 3 days with a calcium of $11.1 \mathrm{mg} / \mathrm{dL}(2.8 \mathrm{mmol} / \mathrm{L})$. After zolendronate and two doses of calcitonin were given, the calcium was $9.0 \mathrm{mg} / \mathrm{dL}(2.3 \mathrm{mmol} / \mathrm{L})$. Cinacalcet was initiated and titrated. For nearly 2 months on cinacalcet monotherapy, she had no more hypercalcemia despite rises in the PTH-RP 143->194 pmol/L (1,348->1,829 ng/L). Nivolumab was discontinued due to disease progression, and the patient died in hospice care without further laboratory studies.

\section{Our case (United States of America)}

We now present a case of HHM treated successfully with cinacalcet. Success being defined as normalization of calcium levels over many months without need for clinic or hospital administration of IV nor s.c. agent and no emergency department visits nor hospital admissions for hypercalcemia urgency or crisis.

Performing labs and reference ranges are provided as follows: Calcium 2.1-2.7 mmol/L, Orlando VA Health Care System, Orlando, Florida, USA; $1,25(\mathrm{OH})_{2}$ D3 43-173 pmol/L Quest Diagnostics, chromatography/ mass spectrometry, Chantilly, Virginia, USA; 25 hydroxy vitamin D (25 (OH) D3) 75-250 nmol/L Quest Diagnostics, immunoassay, Chantilly, Virginia, USA; PTH-RP 14-27 ng/L Quest Diagnostics, immunoassay, Chantilly, Virginia, USA; PTH 1.5-6.8 pmol/L Quest Diagnostics, immunoassay, Chantilly, Virginia, USA. Adjusted calcium level was determined using the following equation: ((4-albumin) $\times$ $0.8)+$ serum calcium. All calcium levels referenced below are adjusted serum levels, as the patient's albumin was low.

A 71-year-old male had a past medical history significant for Von Hippel-Lindau syndrome and metastatic renal cell carcinoma (RCC). The RCC was found to have metastasized (16 years after initial nephrectomy) as evidenced by pulmonary masses, a large pancreatic mass replacing the tail, a right parotid mass, osseous lesions, and numerous hyperdense left renal lesions. Treatment with pazopanib was initiated shortly thereafter.
The patient developed MAH 6 months into therapy. The calcium was $3.1 \mathrm{mmol} / \mathrm{L}$ with PTH $0.6 \mathrm{pmol} / \mathrm{L}$, and 25 $(\mathrm{OH})$ D3 $142 \mathrm{nmol} / \mathrm{L}$, therefore, MAH was presumed. The hypercalcemia responded to zolendronate $4 \mathrm{mg}$ IV on two separate occasions over 11 months (calcium levels normal or slightly elevated) while the patient was able to receive targeted cancer therapy, with a change from pazopanib to nivolumab.

Upon its return, the hypercalcemia at $3.0 \mathrm{mmol} / \mathrm{L}$ was refractory to three doses of denosumab $120 \mathrm{mg}$ SC over 4 weeks. Nivolumab was discontinued due to kidney injury, and prednisone was started. At the time of his consultation with our Endocrinology service, the patient presented with a calcium of $3.7 \mathrm{mmol} / \mathrm{L}$, PTH of $0.2 \mathrm{pmol} / \mathrm{L}$, PTH-RP $47 \mathrm{ng} / \mathrm{L}, 1,25(\mathrm{OH})_{2}$ D3 $238 \mathrm{pmol} / \mathrm{L}$, and $25(\mathrm{OH})$ D3 102 $\mathrm{nmol} / \mathrm{L}$. The patient received IV hydration $3 \mathrm{~L}$ over 6 $\mathrm{h}$ and IV methylprednisolone $40 \mathrm{mg}$ once; he had just received the latest denosumab dose. Day 2, the patient received furosemide $40 \mathrm{mg} \mathrm{IV}$ and $1 \mathrm{~L}$ normal saline IV and was started on cinacalcet $30 \mathrm{mg}$ by mouth (PO) daily. Four days later, the calcium improved to $3.3 \mathrm{mmol} / \mathrm{L}$, and the cinacalcet was increased to $60 \mathrm{mg}$ PO daily. One week after cinacalcet dose escalation, the calcium was $2.8 \mathrm{mmol} / \mathrm{L}$. Due to the very favorable response and uncertainty as to whether this continued dose would incite hypocalcemia, the cinacalcet was reduced back to $30 \mathrm{mg}$ PO daily. Seven days later the calcium had risen to $3.3 \mathrm{mmol} / \mathrm{L}$; the cinacalcet was again increased to $60 \mathrm{mg}$ PO daily. At this time targeted therapy with cabozantanib was started and was given off and on for 10 months. It had been placed on hold for various medical reasons. The calcium level remained normal for 3 months at which time it dropped to low normal at $2.1 \mathrm{mmol} / \mathrm{L}$. Rather than de-escalating the cinacalcet dose by $50 \%$, the dose was simply reduced to $45 \mathrm{mg}$ PO daily. The calcium remained in the normal range for the next 9 months (with a goal to keep the calcium at the upper limits of normal, so as not to incite hypocalcemia), and the PTH normalized to 1.9 pmol/L. During this time the $1,25(\mathrm{OH})_{2}$ D3 normalized and then rose slightly above normal again.

In his 10th month of treatment with cinacalcet, the patient suffered an acute stroke and was hospitalized. During that time, his cinacalcet treatment was interrupted. Resultantly, his calcium rose to $3.6 \mathrm{mmol} / \mathrm{L}$. Cinacalcet was resumed at $90 \mathrm{mg}$ PO daily, and denosumab $120 \mathrm{mg}$ SC was given. By 10 days, the calcium improved to 3.0 $\mathrm{mmol} / \mathrm{L}$, and another dose of denosumab $120 \mathrm{mg}$ SC was given. The calcium normalized in 1 week and remained normal with a normal PTH on cinacalcet monotherapy until he succumbed to his disease 17 days later (Fig. 2). 


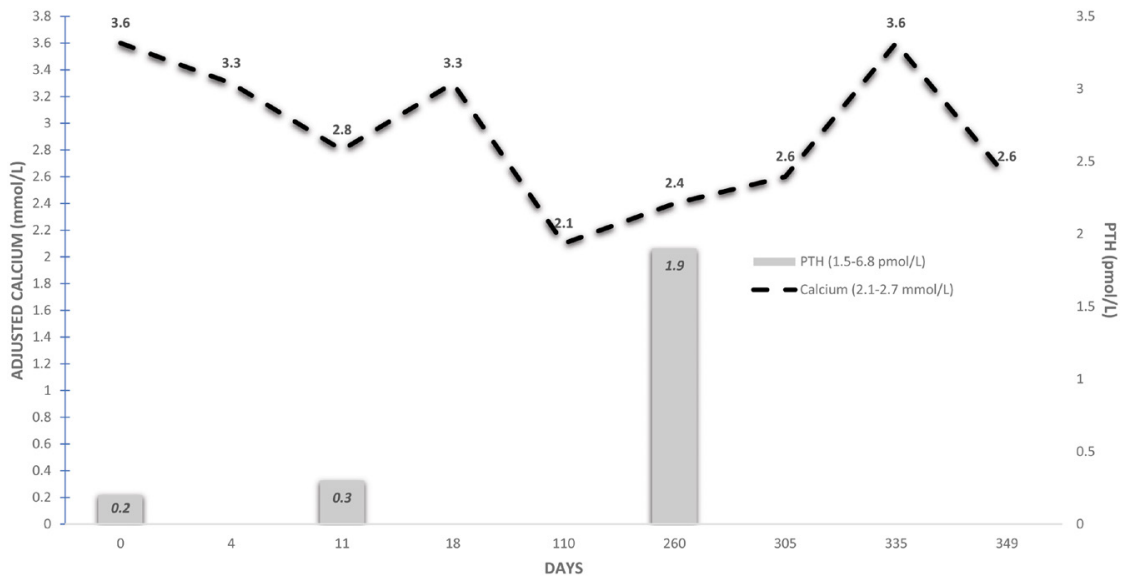

Figure 2

Parathyroid hormone (PTH). The dash line represents calcium response, and the bar denotes change in PTH.
It should be noted that the patient was started on prednisone for chronic kidney inflammation while on nivolumab. It was given off and on prior to and during the course of cinacalcet treatment. Considering the amount of time that the patient was on a stable dose of cinacalcet with normal calcium levels, it is our thought that the prednisone was not significantly influencing calcium levels. Furthermore, while targeted anti-tumor therapies had been on hold, the cinacalcet was, nonetheless, able to maintain normal calcium levels. While the PTH-RP came down to $29 \mathrm{ng} / \mathrm{L}$, it was not profoundly elevated at any given time, and its improvement was only very slight. Therefore, it is postulated that for a given level of PTH-RP, there is not a correlation with the severity of hypercalcemia nor the cinacalcet dose required to achieve normocalcemia (Fig. 3). Changes in 25(OH) D3 were not noteworthy, while there was slight reduction in $1,25(\mathrm{OH})_{2}$ D3 (Table 2).

\section{Discussion}

Our patient acquired HHM that was refractory to bisphosphonate and denosumab therapy. As a result of treatment with cinacalcet, there was reduction in and normalization of calcium. As noted above, other cases show cinacalcet's usefulness in the treatment of HHM. Given that the patients in these cases received multiple therapeutic agents to reduce calcium, it can be difficult to differentiate effects due to cinacalcet and those due to other agents. However, when hypercalcemia is refractory to all conventional modalities yet responds to the addition of cinacalcet, it follows that cinacalcet can serve as adjunctive therapy.

It is well described that the CaSR of the parafollicular $\mathrm{C}$ cells of the thyroid modulates calcitonin release in response to hypercalcemia (3). It is possible that this action could be a mechanism by which cinacalcet lowers calcium in HHM; Colloton describes reduction of PTHRP-mediated calcium levels (accompanied by rise in calcitonin levels) with cinacalcet therapy (58). In our case, the PTH-RP levels did not show significant change, though the calcium showed dramatic response. Certainly, the CaSR's influence on renal calcium disposition and osteoblast and osteoclast function can play a role in cinacalcet's calcium lowering ability.

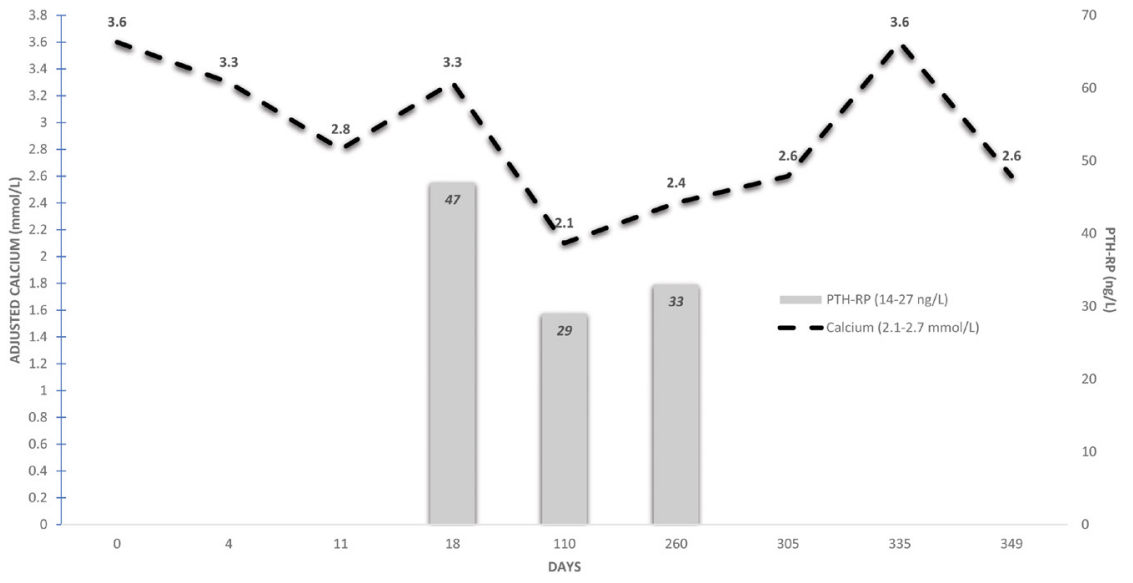

Figure 3

Parathyroid hormone-related peptide (PTH-RP). The dash line represents calcium response, and the bar denotes change in PTH-RP. https://ec.bioscientifica.com https://doi.org/10.1530/EC-20-0487 (c) 2021 The authors Published by Bioscientifica Ltd

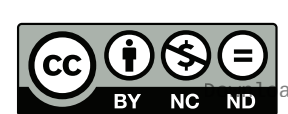

This work is licensed under a Creative Commons Attribution-NonCommercial-NoDerivatives 4.0 elnternational dicense ifica. com at 04/26/2023 12:14:45PM 


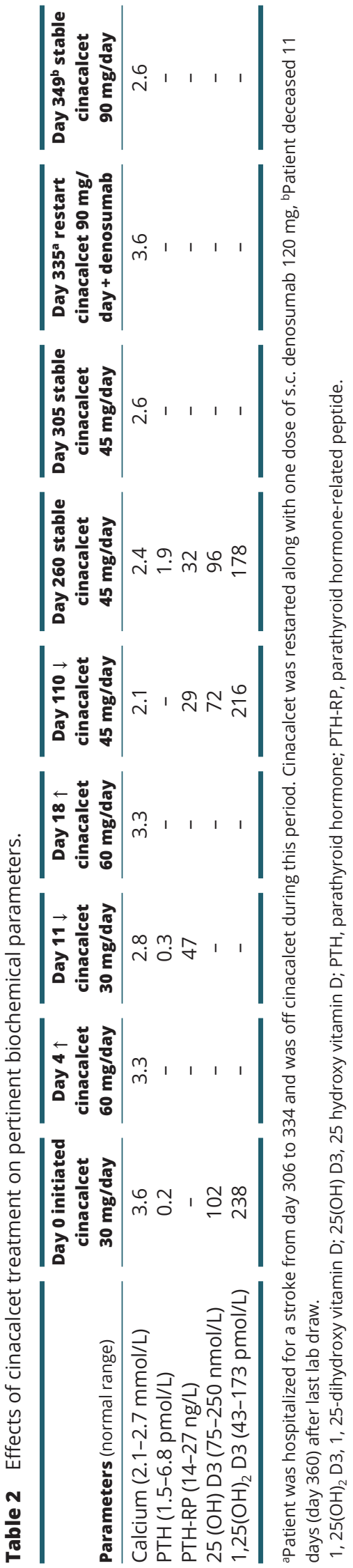

https://ec.bioscientifica.com https://doi.org/10.1530/EC-20-0487

(c) 2021 The authors Published by Bioscientifica Ltd
The patient in our case benefited from a eucalcemic state for nearly 1 year until he succumbed to his disease. It was observed that calcium levels start to respond to cinacalcet in 1 week with normalization of calcium by 2 weeks. While considering each of the cases reviewed here, it is important to note that each patient has variations in calcium homeostasis and in the disease states inciting the MAH and will thus respond differently even to the same cinacalcet dose. Great care should be taken in the monitoring and dosage adjustment of cinacalcet. It is proposed that a temporary drug holiday or a reduction in dose in the setting of hypocalcemia would be preferable to drug discontinuation. This reduces the chance of returning to a hypercalcemic state or a hypercalcemic urgency. Lab draws were more frequent with initiation of cinacalcet, for example within 1 week for the first draw and weekly draws until calcium levels are stable on a given dose. For our case there were a couple of instances of 3-4 weeks between blood draws, since the calcium was quite stable.

Reducing morbidity from $\mathrm{MAH}$ is important to patients in terms of their symptomatology, but it is equally important in terms of their required clinic visits and hospitalizations. While on oral cinacalcet monotherapy for his HHM, our patient remained eucalcemic, and no longer required clinic visits or hospitalizations specifically for treatment of hypercalcemia. Patients have many clinic encounters and hospitalizations resulting from disease treatment and progression of their primary disease; it follows that reducing the need for these encounters by controlling MAH becomes very meaningful to them.

Early on it was suggested that debulking tumor would favorably impact hypercalcemia regardless of the biochemical factors involved, because a debulked tumor could portend reduction of biochemical factors driving hypercalcemia (59). It follows that PTH-RP could be reduced with physical debulking or with targeted tumor therapy. Interestingly, our patient's PTH-RP levels came down only slightly, with cinacalcet therapy; the significance of this is unknown. Even with only minimal reductions of PTH-RP and progression of cancer until the time of death, cinacalcet was able to achieve a eucalcemic state.

\section{Conclusion}

Even as recent as 2014, it has been suggested that palliation of symptoms related to MAH is essential and clinically meaningful for patients, given the continued poor

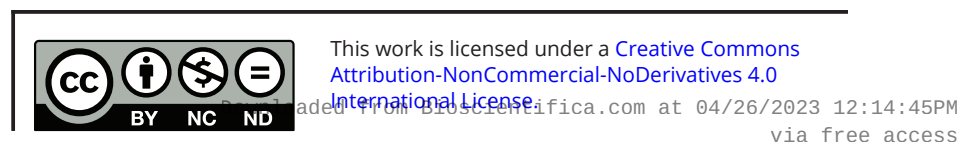


prognosis and high morbidity and mortality associated with MAH (49). Historically, agents have been temporizing and have not impacted patient survival. The ideal agent for long-term treatment of MAH that was hoped for in the early 1980s was an oral agent which maintains the serum calcium in the normal or near normal range (39). We suggest that cinacalcet can be that oral agent, reducing patients' time in the hospital and clinic settings. It is welltolerated and can maintain calcium levels in the normal range. This has a direct, major impact on morbidity. Treatment of MAH to this level of success can increase patient quality of life while targeted cancer therapies can work to improve survival. So far, this is the only agent to treat MAH suggested to favorably impact quality of life. Studies are needed to determine the possible impact of the achievement of eucalcemia on survival with MAH. While it is true that not all patients may respond, depending on the aggressiveness of the late stages of cancer, especially where death is imminent, it seems worthwhile to afford the possible benefit.

Cinacalcet is approved for secondary hyperparathyroidism, parathyroid carcinoma-associated hypercalcemia, and severe hypercalcemia associated with primary hyperparathyroidism. The use of cinacalcet is novel in the treatment of $\mathrm{MAH} / \mathrm{HHM}$; the case presented here responded successfully to this therapy (reduction of calcium levels to normal). First line agents for MAH historically have been IV or SC, and no agent had been uniformly safe and effective over a long period of time $(23,39)$. It is proposed here that oral cinacalcet can favorably influence calcium homeostasis safely over an extended period of time in the setting of HHM as adjunctive therapy or (in some cases) monotherapy. Given that there is often a humoral component to osteolytic MAH, it is postulated that cinacalcet could benefit patients regardless of the predominating etiology of MAH in any given case.

\section{Goals of future therapeutic modalities}

Prior to identifying PTH-RP or its receptor, it was postulated that blocking the humoral substance driving the hypercalcemia would be a possible therapeutic option (17). Recognizing the need to target renal resorption of calcium, it was suggested that drugs are needed to inhibit PTH or PTH-RP action or production, or that antibodies are needed to inhibit PTH-RP $(19,53,60)$. Further research elucidating this interplay is warranted.

Given that these case reports showed improvement of calcium in $\mathrm{MAH}$, there is promising evidence that cinacalcet can be employed in this setting. Future consideration should be given to studies addressing the efficacy of cinacalcet in calcium normalization, improvement of quality of life, and impact on survival in patients with MAH. Even though the exact mechanism of action for cinacalcet's reduction in calcium in this setting is not entirely elucidated, we can still afford patients the possible benefit from it.

\section{Declaration of interest}

The published viewpoints are those of the individual authors and do not represent the official stance or statements of the respective academic and/or governmental agencies with which the authors are affiliated.

\section{Funding}

This work did not receive any specific grant from any funding agency in the public, commercial or not-for-profit sector.

\section{Author contribution statement}

S O'Callaghan conceived of the idea and subject matter for this review article. S O'Callaghan and $\mathrm{H}$ Yau were responsible for the care of the patient presented in the case along with the acquisition, analysis, and interpretation of data. Both authors contributed to the drafting and revising of the manuscript critically for important intellectual content.

\section{References}

1 Spinazze S \& Schrijvers D. Metabolic emergencies. Critical Reviews in Oncology/Hematology 200658 79-89. (https://doi.org/10.1016/j. critrevonc.2005.04.004)

2 Lewis MA, Hendrickson AW \& Moynihan TJ. Oncologic emergencies: pathophysiology, presentation, diagnosis, and treatment. $C A$ : A Cancer Journal for Clinicians 201161 287-314. (https://doi. org/10.3322/caac.20124)

3 Gardner DG. Endocrine emergencies. In Greenspan's Basic and Clinical Endocrinology, 8th ed., chapter 25, pp. 882-884. Eds DG Gardner \& D Shoback. New York: McGraw Hill, 2018.

4 Stewart AF. Clinical practice. Hypercalcemia associated with cancer. New England Journal of Medicine 2005352 373-379. (https://doi. org/10.1056/NEJMcp042806)

5 Ralston SH, Gallacher SJ, Patel U, Campbell J \& Boyle IT. Cancerassociated hypercalcemia: morbidity and mortality. Clinical experience in 126 treated patients. Annals of Internal Medicine 1990 112 499-504. (https://doi.org/10.7326/0003-4819-112-7-499)

6 De Wit S \& Cleton FJ. Hypercalcemia in patients with breast cancer: a survival study. Journal of Cancer Research and Clinical Oncology 1994 120 610-614. (https://doi.org/10.1007/BF01212816)

7 Coleman RE \& Rubens RD. The clinical course of bone metastases from breast cancer. British Journal of Cancer 198755 61-66. (https:// doi.org/10.1038/bjc.1987.13)

8 Chen YW, Chen IL, Lin IC \& Kao SY. Prognostic value of hypercalcemia and leukocytosis in resected oral squamous cell carcinoma. British Journal of Oral and Maxillofacial Surgery 201452 425-431. (https://doi.org/10.1016/j.bjoms.2014.02.014)

9 Le Tinier F, Vanhuyse M, Penel N, Dewas S, El-Bedoui S \& Adenis A. Cancer-associated hypercalcaemia in squamous-cell malignancies: a survival and prognostic factor analysis. International Journal of Oral 
and Maxillofacial Surgery 201140 938-942. (https://doi.org/10.1016/j. ijom.2010.11.028)

10 Donovan PJ, Achong N, Griffin K, Galligan J, Pretorius CJ \& McLeod DS. PTHrP-mediated hypercalcemia: causes and survival in 138 patients. Journal of Clinical Endocrinology and Metabolism 2015 100 2024-2029. (https://doi.org/10.1210/jc.2014-4250)

11 Ramos REO, Perez Mak M, Alves MFS, Piotto GHM, Takahashi TK, Gomes da Fonsec L, Silvino MCM, Hoff PM \& de Castro Jr G. Malignancy-related hypercalcemia in advanced solid tumors: survival outcomes. Journal of Global Oncology 20173 728-733. (https://doi. org/10.1200/JGO.2016.006890)

12 Pelosof LC \& Gerber DE. Paraneoplastic syndromes: an approach to diagnosis and treatment. Mayo Clinic Proceedings 201085 838-854. (https://doi.org/10.4065/mcp.2010.0099)

13 Wright JD, Tergas AI, Ananth CV, Burke WM, Hou JY, Chen L, Neugut AI, Richards CA \& Hershman DL. Quality and outcomes of treatment of hypercalcemia of malignancy. Cancer Investigation 201533 331-339. (https://doi.org/10.3109/07357907.2015. 1047506)

14 Ling PJ, A'Hern RP \& Hardy JR. Analysis of survival following treatment of tumor-induced hypercalcemia with intravenous pamidronate (APD). British Journal of Cancer 199572 206-209. (https://doi.org/10.1038/bjc.1995.304)

15 Penel N, Dewas S, Hoffman A \& Adenis A. Cancer-associated hypercalcemia: validation of a bedside prognostic score. Supportive Care in Cancer 200917 1133-1135. (https://doi.org/10.1007/s00520009-0607-5)

16 Cabot RC \& Mallory TB. Case records of the Massachusetts General Hospital: case 27461. New England Journal of Medicine 1941225 789-791. (https://doi.org/10.1056/NEJM194111132252007)

17 Powell D, Singer FR, Murray TM, Minkin C \& Potts JT Jr. Nonparathyroid humoral hypercalcemia in patients with neoplastic diseases. New England Journal of Medicine 1973289 176-181. (https:// doi.org/10.1056/NEJM197307262890403)

18 Sherwood LM \& Castleman B. Case records of the Massachusetts General Hospital: case 15-1971-hypercalcemia with chronic pulmonary disease. New England Journal of Medicine 1971284 839-847. (https://doi.org/10.1056/NEJM197104152841508)

19 Martin TJ \& Suva LJ. Parathyroid hormone-related protein in hypercalcaemia of malignancy. Clinical Endocrinology 198931 631-647. (https://doi.org/10.1111/j.1365-2265.1989.tb01288.x)

20 Vacher-Coponat H, Opris A, Denizot A, Dussol B \& Berland Y. Hypercalcaemia induced by excessive parathyroid hormone secretion in a patient with neuroendocrine tumor. Nephrology, Dialysis, Transplantation 200520 2832-2835. (https://doi.org/10.1093/ndt/ gfi065)

21 Martin TJ \& Atkins D. Biochemical regulators of bone resorption and their significance in cancer. Essays in Medical Biochemistry 19794 49-82.

22 Myers WPL. Hypercalcemia in neoplastic disease. Archives of Surgery 196080 308-318. (https://doi.org/10.1001/ archsurg.1960.01290190128024)

23 Ralston SH, Fogelman I, Gardiner MD \& Boyle IT. Relative contribution of humoral and metastatic factors to the pathogenesis of hypercalcaemia of malignancy. BMJ 1984288 1405-1408. (https:// doi.org/10.1136/bmj.288.6428.1405)

24 Mundy GR. Pathogenesis of hypercalcemia of malignancy. Clinical Endocrinology 198523 705-714. (https://doi. org/10.1111/j.1365-2265.1985.tb01132.x)

25 Davies M, Hayes ME, Yin JAL, Berry JL \& Mawer EB. Abnormal synthesis of 1,25-dihydroxyvitamin $\mathrm{D}$ in patients with malignant lymphoma. Journal of Clinical Endocrinology and Metabolism $1994 \mathbf{7 8}$ 1202-1207. (https://doi.org/10.1210/jcem.78.5.8175979)

26 Evans KN, Taylor H, Zehnder D, Kilby MD, Bulmer JN, Shah F, Adams JS \& Hewison M. Increased expression of 25-hydroxyvitamin D-1alpha-hydroxylase in dysgerminomas: a novel form of humoral hypercalcemia of malignancy. American Journal of Pathology 2004165 807-813. (https://doi.org/10.1016/s0002-9440(10)63343-3)

27 Hibi M, Hara F, Tomishige H, Nishida Y, Kato T, Okumura N, Hashimoto T \& Kato R. 1,25-Dihydroxyvitamin D-mediated hypercalcemia in ovarian dysgerminoma. Pediatric Hematology and Oncology 200825 73-78. (https://doi. org/10.1080/08880010701774033)

28 Grill V, Ho P, Body JJ, Johanson N, Lee SC, Kukreja SC, Moseley JM \& Martin TJ. Parathyroid hormone-related protein: elevated levels in both humoral hypercalcemia of malignancy and hypercalcemia complicating metastatic breast cancer. Journal of Clinical Endocrinology and Metabolism 199173 1309-1315. (https://doi.org/10.1210/jcem73-6-1309)

29 Soyfoo MS, Brenner K, Paesmans M \& Body JJ. Non-malignant causes of hypercalcemia in cancer patients: a frequent and neglected occurrence. Supportive Care in Cancer 201321 1415-1419. (https:// doi.org/10.1007/s00520-012-1683-5)

30 Burtis WJ, Wu T, Bunch C, Wysolmerski JJ, Insoqna KL, Weir EC, Broadus AE \& Stewart AF. Identification of a novel 17,000 dalton parathyroid hormone-like adenylate cyclase-stimulating protein from a tumor associated with humoral hypercalcemia of malignancy. Journal of Biological Chemistry 1987262 7151-7156.

31 Schneider HG, Kartsogiannis V, Zhou H, Chou ST, Martin TJ \& Grill V. Parathyroid hormone-related protein mRNA and protein expression in multiple myeloma: a case report. Journal of Bone and Mineral Research 199813 1640-1643. (https://doi.org/10.1359/ jbmr.1998.13.10.1640)

32 Ralston SH, Danks J, Hayman J, Fraser WD, Stewart CS \& Martin TJ. Parathyroid hormone-related protein of malignancy: immunohistochemical and biochemical studies in normocalcemic and hypercalcemic patients with cancer. Journal of Clinical Pathology 199144 472-476. (https://doi.org/10.1136/jcp.44.6.472)

33 Roodman GD. Mechanisms of bone metastasis. New England Journal of Medicine 2004350 1655-1664. (https://doi.org/10.1056/ NEJMra030831)

34 Mundy GR. Mechanisms of osteolytic bone destruction. Bone 199112 (Supplement 1) S1-S6. (https://doi.org/10.1016/87563282(91)90057-p)

35 Body JJ, Niepel D \& Tonini G. Hypercalcemia and hypocalcemia: finding the balance. Supportive Care in Cancer 201725 1639-1649. (https://doi.org/10.1007/s00520-016-3543-1)

36 Horwitz MJ \& Stewart AF. Malignancy-associated hypercalcemia and medical management. In Endocrinology, 6th ed., Chapter 63, pp. 1198-1209. Eds JL Jameson, LJ DeGroot \& D de Krester. Philadelphia: Saunders Elsevier, 2010.

37 Clemens TL, Cormier S, Eichinger A, Endlich K, Fiaschi-Taesch N, Fischer E, Friedman PA, Karaplis AC, Massfelder T, Rossert J, et al. Parathyroid hormone-related protein and its receptors: nuclear functions and roles in the renal and cardiovascular systems, the placental trophoblasts and the pancreatic islets. British Journal of Pharmacology 2001134 1113-1136. (https://doi.org/10.1038/ sj.bjp.0704378)

38 Martin TJ \& Grill V. Hypercalcemia in cancer. Journal of Steroid Biochemistry and Molecular Biology 199243 123-129. (https://doi. org/10.1016/0960-0760(92)90196-p)

39 Mundy GR \& Martin TJ. The hypercalcemia of malignancy: pathogenesis and management. Metabolism: Clinical and Experimental 198231 1247-1277. (https://doi.org/10.1016/00260495(82)90012-9)

40 Moseley JM, Kubota M, Diefenbach-Jagger H, Wettenhall REH, Kemp BE, Suva LJ, Rodda CP, Ebeling PR, Hudson PJ \& Zajac JD. Parathyroid hormone-related protein purified from a human lung cancer cell line. PNAS 198784 5048-5052. (https://doi.org/10.1073/ pnas.84.14.5048)

41 Suva LJ, Winslow GA, Wettenhall REH, Hammonds RG, Moseley JM, Diefenbach-Jagger H, Rodda CP, Kemp BE, Rodriguez H \& Chen EY. 
A parathyroid hormone-related protein implicated in malignant hypercalcemia: cloning and expression. Science 1987237 893-896. (https://doi.org/10.1126/science.3616618)

42 Kemp BE, Moseley JM, Rodda CP, Ebeling PR, Wettenhall REH, Stapleton D, Diefenbach-Jagger H, Ure F, Michelangeli VP \& Simmons HA. Parathyroid hormone-related protein of malignancy: active synthetic fragments. Science 1987238 1568-1570. (https://doi. org/10.1126/science.3685995)

43 Naafs MAB. Parathyroid hormone related peptide (PTHrP): a minireview. Endocrinology and Metabolism International Journal 2017 5 00139. (https://doi.org/10.15406/emij.2017.05.00139)

44 Mangin M, Ikeda K, Dreyer BE \& Broadus AE. Isolation and characterization of the human parathyroid hormone-like peptide gene. PNAS 198986 2408-2412. (https://doi.org/10.1073/ pnas.86.7.2408)

45 Yang Y \& Wang B. PTH1R-CaSR cross talk: new treatment options for breast cancer osteolytic bone metastases. International Journal of Endocrinology 20182018 7120979. (https://doi. org/10.1155/2018/7120979)

46 Collins MT, Skarulis MC, Bilezikian JP, Silverberg SJ, Spiegel AM $\&$ Marx SJ. Treatment of hypercalcemia secondary to parathyroid carcinoma with a novel calcimimetic agent. Journal of Clinical Endocrinology and Metabolism 199883 1083-1088. (https://doi. org/10.1210/jcem.83.4.4726)

47 Mirrakhimov AE. Hypercalcemia of malignancy: an update on pathogenesis and management. North American Journal of Medical Sciences 20157 483-493. (https://doi.org/10.4103/19472714.170600)

48 Kaiser W, Biesenbach G, Kramer R \& Zazqornik J. Calcium free hemodialysis: an effective therapy in hypercalcemic crisis-report of 4 cases. Intensive Care Medicine 198915 471-474. (https://doi. org/10.1007/BF00255605)

$49 \mathrm{Hu}$ MI, Glezerman IG, Leboulleux S, Insogna K, Gucalp R, Misiorowski W, Yu B, Zorsky P, Tosi D, Bessudo A, et al. Denosumab for treatment of hypercalcemia of malignancy. Journal of Clinical Endocrinology and Metabolism 201499 3144-3152. (https://doi. org/10.1210/jc.2014-1001)

50 Adami S \& Rossini M. Hypercalcemia of malignancy: pathophysiology and treatment. Bone 199213 (Supplement 1) S51-S55. (https://doi.org/10.1016/s8756-3282(09)80010-0)
51 Thosani S \& Hu MI. Denosumab: a new agent in the management of hypercalcemia of malignancy. Future Oncology 201511 2865-2871. (https://doi.org/10.2217/fon.15.232)

52 Bech A, Smolders K, Telting D \& de Boer H. Cinacalcet for hypercalcemia caused by pulmonary squamous cell carcinoma producing parathyroid hormone-related peptide. Case Reports in Oncology 20125 1-8. (https://doi.org/10.1159/000335676)

53 Sternlicht H \& Glezerman IG. Hypercalcemia of malignancy and new treatment options. Therapeutics and Clinical Risk Management 201511 1779-1788. (https://doi.org/10.2147/TCRM.S83681)

54 Whitfield PL \& Carroll RW. THR-319: Cinacalcet use in PTHrPsecreting GEP-NETs: a new management option for humoral hypercalcemia of malignancy? In Endocrine Society's 97th Annual Meeting and Expoo, March 5-8, San Diego, 2015.

55 Valdes-Socin H, Almanza MR, Fernandez-Ladreda MT, Daele DV, Polus M, Chavez M \& Beckers A. Use of Cinacalcet and sunitinib to treat hypercalcaemia due to a pancreatic neuroendocrine tumor. Archives of Endocrinology and Metabolism 201761 506-509. (https:// doi.org/10.1590/2359-3997000000291)

56 Asonitis N, Kassi E, Kokkinos M, Giovanopoulos I, Petychaki F \& Goqas H. Hypercalcemia of malignancy treated with Cinacalcet. Endocrinology, Diabetes and Metabolism Case Reports 20172017 170118. (https://doi.org/10.1530/EDM-17-0118)

57 Sheehan M, Tanimu S, Tanimu Y, Engel J \& Onitilo A. Cinacalcet for the treatment of humoral hypercalcemia of malignancy: an introductory case report with a pathophysiologic and therapeutic review. Case Reports in Oncology 202013 321-329. (https://doi. org/10.1159/000506100)

58 Colloton M, Shatzen E, Wiemann B, Starnes C, Scully S, Henley C \& Martin D. Cinacalcet attenuates hypercalcemia observed in mice bearing either rice H-500 Leydig cell or C26-DCT colon tumors. European Journal of Pharmacology 2013712 8-15. (https://doi. org/10.1016/j.ejphar.2013.04.013)

59 Perlia CP, Gubisch NJ, Wolter J, Edelberg D, Dederick MM \& Taylor 3rd SG. Mithramycin treatment of hypercalcemia. Cancer 197025 389-394. (https://doi.org/10.1002/10970142(197002)25:2<389::aid-cncr2820250217>3.0.co;2-x)

60 Grill V \& Martin TJ. Hypercalcemia of malignancy. Reviews in Endocrine and Metabolic Disorders 20001 253-263. (https://doi.org/10. 1023/a:1026597816193)

Received in final form 24 November 2020

Accepted 3 December 2020

Accepted Manuscript published online 8 December 2020 https://ec.bioscientifica.com https://doi.org/10.1530/EC-20-0487
(C) 2021 The authors Published by Bioscientifica Ltd
This work is licensed under a Creative Commons Attribution-NonCommercial-NoDerivatives 4.0 International License.ifica com at $04 / 26 / 2023$ 12:14:45PM 